\title{
PROGRAM INTERVENSI TERPADU ANAK BERKEBUTUHAN KHUSUS: PROSES PENGEMBANGAN KURIKULUM
}

\author{
Zaini Sudarto \\ Pendidikan Luar Biasa, Fakultas Ilmu Pendidikan, Universitas Negeri Surabaya \\ zainisudarto@unesa.ac.id
}

\author{
Khofidotur Rofiah, Febrita Ardianingsih, Sujarwanto \\ Pendidikan Luar Biasa, Fakultas Ilmu Pendidikan, Universitas Negeri Surabaya \\ khofidoturrofiah@unesa.ac.id, febritaardianingsih@unesa.ac.id, sujarwanto@unesa.ac.id
}

\begin{abstract}
Abstrak
Pengembangan kurikulum program intervensi anak berkebutuhan khusus menjadi penting untuk mendukung terselenggaranya pembelajaran dan layanan program intervensi yang efektif. Lebih-lebih berkait dengan keberhasilan misi Unit Layanan Anak Berkebutuhan Khusus Unesa untuk memberikan solusi pendidikan bagi anak berkebutuhan khusus pada semua kalangan. Untuk terselenggranya layanan yang memadai dan professional, dibutuhkan dukungan adanya pengembangan perangkat kurikulum yang sesuai dengan karakteristik, kemampuan, dan kebutuhan klien. Sehingga dengan dikembangnya kurikulum program intervensi, klien dan keluarga anak berkebutuhan khusus mendapatkan pelayanan yang optimal dan terbaik bagi anak mereka. Pengembangan kurikulum progrsm intervensi terpadu anak berkebutuhan khusus dalam peneilitian ini menggunakan rancangan pengembangan 4D-Model. Model ini dikembangkan oleh S. Thagarajan, Dorothy S. Semmel, dan Melvyn I. Semmel. Model pengembangan 4D terdiri atas 4 tahap utama yaitu: (1) Define (Pembatasan), (2) Design (Perancangan), (3) Develop (Pengembangan) dan Disseminate (Penyebaran).

Penelitian ini dilaksanakan selama 8 bulan, sehingga berdasarkan desain model pengembangan tersebut, kegiatan penilitian pada tahun pertama difokuskan pada pelaksanaaan 3 tahapan yaitu (1) pendefinisian, (2) perencanaan/desain, dan (3) pengembangan.
\end{abstract}

Kata kunci: Kurikulum, Program Intervensi Terpadu, Prosedur Pengembangan

\begin{abstract}
Curriculum development of children's intervention programs is importance to support the implementation of effective learning and intervention program services. More related to the success of the mission of Children With Special Needs Serivce Unit Unesa to provide educational solutions for children with special needs in all circles. For the implementation of qualify and professional services, competency improvement support is needed in accordance with the characteristics, abilities and needs of the client. Associated with the development of curriculum programs, clients and families with special needs get the best and optimal service for their children. Curriculum development is specifically designed for children in this study using the 4D-Model development planning. This model was developed by S. Thagarajan, Dorothy S. Semmel, and Melvyn I. Semmel. The 4D Development Model consists of 4 main: (1) Define, (2) Design, (3) Develop, and (4) Disseminate. This research was conducted for 8 months, so based on the design of the development model, the research activities in the first year were approved in the implementation of 3 stages, (1) definition, (2) planning / design, and (3) development.
\end{abstract}

Keywords: Curriculum, Integrated Intervention Program, Development Procedure 


\section{PENDAHULUAN}

Kurikulum merupakan salah satu bagian penting terjadinya suatu proses pendidikan. Karena suatu pendidikan tanpa adanya kurikulum akan kelihatan amburadul dan tidak teratur. Hal ini akan menimbulkan perubahan dalam perkembangan kurikulum, khususnya di Indonesia. Kurikulum merupakan salah satu alat untuk mencapai tujuan pendidikan, dan sekaligus digunakan sebagai pedoman dalam pelaksanaan proses belajar mengajar pada berbagai jenis dan tingkat sekolah. Kurikulum menjadi dasar dan cermin falsafah pandangan hidup suatu bangsa, akan diarahkan kemana dan bagaimana bentuk kehidupan bangsa ini di masa depan, semua itu ditentukan dan digambarkan dalam suatu kurikulum pendidikan. Kurikulum haruslah dinamis dan terus berkembang untuk menyesuaikan berbagai perkembangan yang terjadi pada masyarakat dunia dan haruslah menetapkan hasilnya sesuai dengan yang diharapkan.

Sejak kurikulum dipakai dalam dunia pendidikan yang intinya dapat membentuk perilaku anak didik, sehingga kurikulum selalu terkait dengan pendidikan pada tingkat Pra Sekolah, Dasar, Menengah maupun Tinggi. Begitu juga halnya, kurikulum bagi anak berkebutuhan khusus (ABK) tidak terlepas dari kurikulum yang menaunginya. Anak berkebutuhan khusus (ABK) dan anak normal, pasti sama dalam tujuan dalam kurikulumnya, yakni sama-sama untuk membentuk perilaku anak didik. Akan tetapi, disatu sisi, anak berkebutuhan khusus (ABK) dan anak normal, tingkat kurikulumnya sama saja, tetapi disisi lain perbedaanya pasti ada, yakni pada evaluasinya. Perbedaan yang ada, bukanlah menjadi kesenjangan tetapi seharusnya dapat menciptakan kebersamaan. Oleh karena itu, pendidikan pada dasarnya adalah untuk mengajarkan pendidikan yang positif kepada anak, sehingga anak yang normal ataupun anak berkebutuhan khusus, sama saja dalam hal tujuan pendidikannya.

\section{METODE}

Pengembangan Perangkat pembelajaran dalam peneilitian ini menggunakan rancangan pengembangan 4D-Model . Model ini dikembangkan oleh S. Thagarajan, Dorothy S. Semmel, dan Melvyn I. Semmel. Model pengembangan 4D terdiri atas 4 tahap utama yaitu: (1) Define (Pembatasan), (2) Design (Perancangan), (3) Develop (Pengembangan) dan Disseminate (Penyebaran).

Secara garis besar keempat tahap tersebut sebagai berikut:

1) Tahap Pendefinisian (define). Tujuan tahap ini adalah menentapkan dan mendefinisikan syaratsyarat pembelajaran di awali dengan analisis tujuan dari batasan materi yang dikembangkan perangkatnya.

2) Tahap Perencanaan (Design ). Tujuan tahap ini adalah menyiapkan prototipe bahan ajar. 
3) Tahap Pengembangan (Develop). Tujuan tahap ini adalah untuk menghasilkan bahan ajar yang sudah direvisi berdasarkan masukan dari hasil validasi ahli.

4) Tahap penyebaran (Disseminate). Pada tahap ini merupakan tahap bahan ajar yang telah dikembangkan pada skala yang lebih luas dengan tujuan untuk menguji efektivitas penggunaan perangkat di dalam proses pembelajaran.

Penelitian ini dilaksanakan selama 8 bulan, sehingga berdasarkan desain model pengembangan tersebut, kegiatan penilitian pada tahun pertama difokuskan pada pelaksanaaan 3 tahapan yaitu (1) pendefinisian, (2) perencanaan/desain, dan (3) pengembangan. Secara lebih terinci tahapan penelitian dilaksanakan sebagai berikut:

Pada tahapan pengembangan prototipe, penelitian difokuskan pada beberapa kegiatan sebagai berikut:

1. Melakukan analisis karakteristik klien (anak berkebutuhan khusus) di Unit Layanan ABK Universitas Negeri Surabaya.

2. Melakukan kajian standar kompetensi yang ditetapkan.

3. Mengidentifikasi persepsi dan ekspektasi orang tua ABK.

4. Analisis temuan pada kegiatan (a-c) yang akan menjadi dasar dan bahan pertimbangan dalam pengembangan perangkat kurikulum program intervensi $\mathrm{ABK}$.

5. Memilih dan menetapkan ruang lingkup materi, tingkatan kompleksitas materi, pendekatan program intervensi.

6. Mengembangkan perangkat kurikulum program intervensi ABK

7. Uji Validasi Ahli

8. Melakukan revisi perangkat pembelajaran

9. Dihasilkan prototifa perangkat kurikulum program intervensi ABK. (siap diuji coba)

\section{HASIL DAN PEMBAHASAN}

Hasil penelitian yang diperoleh dari proses pengembangan yang telah dilakukan oleh tim peneliti adalah sebagai berikut:

1. Tahap Pendefinisian (Define). Tujuan tahap ini adalah menentapkan dan mendefinisikan syaratsyarat pembelajaran di awali dengan analisis tujuan dari batasan materi yang dikembangkan perangkatnya.

2. Tahap Perencanaan (Design). Tujuan tahap ini adalah menyiapkan prototipe bahan ajar.

3. Tahap Pengembangan (Develop). Tujuan tahap ini adalah untuk menghasilkan bahan ajar yang sudah direvisi berdasarkan masukan dari hasil validasi ahli. 


\section{Tahap Pendefinisian (Define)}

a. Melakukan analisis karakteristik klien (anak berkebutuhan khusus) di Unit Layanan ABK Universitas Negeri Surabaya. Tahap ini merupakan tahapan persiapan pengembangan yang dilakukan melalui observasi dan indentifikasi masalah dan kebutuhan di lapangan dengan cara mengidentifikasi karakteristik klien ULABK. Berikut adalah table daftar klien beserta karakteristik hambatan yang dimiliki.

Tabel 1 Daftar klien dan Jenis Hambatan ULABK Unesa

\begin{tabular}{|c|c|c|}
\hline No & Nama Klien & Jenis Hambatan \\
\hline 1. & Vanda & Tunarungu \\
\hline 2. & Dika & Tunagrahita \\
\hline 3. & Azka & Autis \\
\hline 4. & Azam & Speech Delay \\
\hline 5. & Ardra & Tunarungu \\
\hline 6. & Violet & Autis \\
\hline 7. & Charles & Autis \\
\hline 8. & William & Autis \\
\hline 9. & Hatten & Autis \\
\hline 10. & Devian & Autis \\
\hline 11. & Dion & Autis \\
\hline 12. & Alice & Autis \\
\hline 13. & Kyle Phoenix & Autis \\
\hline 14. & Feo & Autis \\
\hline 15. & Yoel & Lambat Belajar \\
\hline 16. & Oxcel & Autis \\
\hline 17. & Naila & Tunagrahita \\
\hline 18. & Angel & Autis \\
\hline 19. & Charles & Autis \\
\hline 20. & Yaya & Autis \\
\hline 21. & Rere & Tunarungu \\
\hline 22. & Jesslyn & Autis \\
\hline 23. & Stand & Autis \\
\hline 24. & Lucky & Autis \\
\hline 25. & Michael & Autis \\
\hline 26. & Saskia & Lambat belajar \\
\hline 27. & Lingga & Autis \\
\hline 28. & Farhan & Tunarungu \\
\hline 29. & Dareel & Tunarungu \\
\hline 30. & Devon & Autis \\
\hline 31. & Allen & Downsyndrome, Autis \\
\hline 32. & Jerico & Autis \\
\hline 33. & Izzah & Tunarungu \\
\hline 34. & Rafa & Autis \\
\hline 35. & Said & Tuna ganda \\
\hline 36. & Farel & Autis \\
\hline
\end{tabular}




\begin{tabular}{l|ll} 
37. & Dinda (Lia) & Cerebral Palsy \\
38. & Danang & Autis \\
39. & Alifa & Autis \\
40. & Azzam & Tunarungu \\
41. & Reni & Tunagrahita \\
42. & Riski & Autis \\
43. & Naila & Tunagrahita \\
44. & Dika & Tunagrahita \\
45. & Fariel & ATD \\
& & (Lambat jalan) \\
46. & Ken & Speech delay \\
47. & Mada & Gangguan Perilaku \\
48. & Riski & Autis \\
49. & Nino & Autis \\
50. & Putri & Tunanetra \\
51. & Davina & Autis
\end{tabular}

b. Melakukan kajian standar kompetensi yang ditetapkan.

Review kepustakaan merupakan tahapan yang penting dilakukan sebelum melakukan sebuah penelitian pengembangan untuk mengetahui landasan teori yang menjadi dasar sebuah pengembangan yang dilakukan.

c. Mengidentifikasi persepsi dan ekspektasi orang tua ABK.

\section{Tahap Perencanaan (Design)}

a. Analisis temuan pada kegiatan sebelumnya yang akan menjadi dasar dan bahan pertimbangan dalam pengembangan perangkat kurikulum program intervensi $\mathrm{ABK}$.

b. Memilih dan menetapkan ruang lingkup materi, tingkatan kompleksitas materi, pendekatan program intervensi.

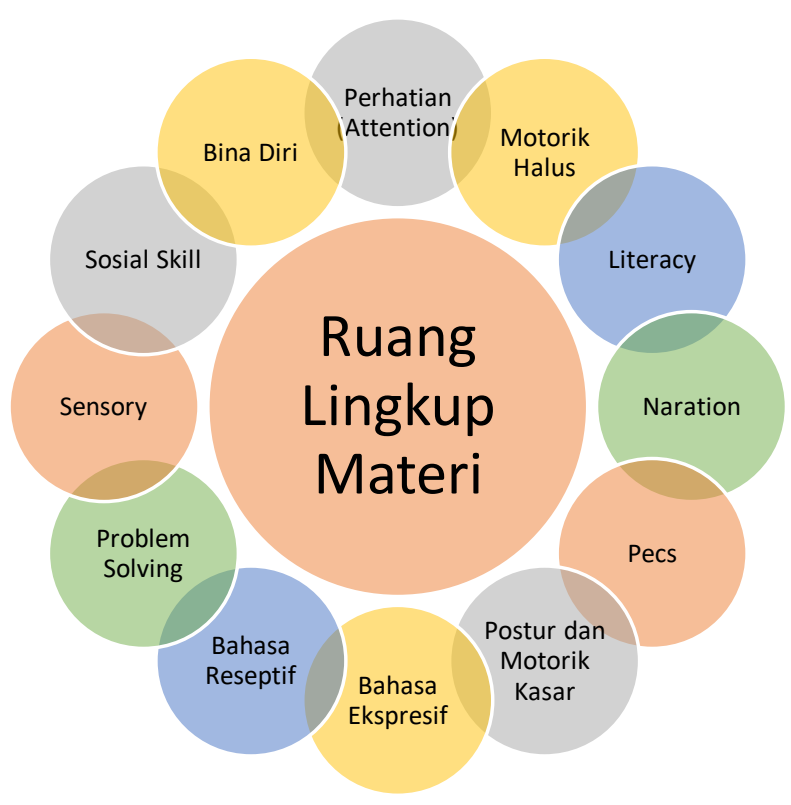




\section{Tahap Pengembangan (Develop)}

Mengembangkan perangkat kurikulum program intervensi ABK. Tahap ini merupakan tahapan pengembangan yang dilakukan berdasarkan hasil observasi dan indentifikasi masalah dan kebutuhan di lapangan dan review beberapa referensi. Berikut ini merupakan aspek dan target sebagau dasar pengembangan kurikulum yang disusun.

Tabel 2 Aspek dan Target Kompetensi Klien ULABK Unesa

\begin{tabular}{|c|c|c|}
\hline No & Aspek & Target \\
\hline 1 & $\begin{array}{l}\text { Perhatian } \\
\text { (Attention) }\end{array}$ & $\begin{array}{l}\text { - Berpartisipasi/turut serta dalam kegiatan yang } \\
\text { dilakukan dengan Guru/Terapis } \\
\text { - Meningkatkan kemampuan tertentu untuk turut } \\
\text { serta lebih lama dalam perhatian dan tugas }\end{array}$ \\
\hline 2 & Motorik Halus & $\begin{array}{l}\text { - Meningkatkan kemampuan untuk menggunakan } \\
\text { tangan yang dominan saat membawa sesuatu di } \\
\text { berbagai kegiatan motorik halus }\end{array}$ \\
\hline 3 & Literacy & $\begin{array}{l}\text { - Meningkatkan kertampilan kesadaran bunyi } \\
\text { bahasa untuk kegiatan membaca dan menulis }\end{array}$ \\
\hline 4 & Naration & $\begin{array}{l}\text { - Meningkatkan kemampuan untuk mengingat dan } \\
\text { menceritakan kembali kejadian / kegiatan yang } \\
\text { sedang berlangsung }\end{array}$ \\
\hline 5 & Pecs & $\begin{array}{l}\text { - Meningkatkan komunikasi ekspresif fungsional } \\
\text { menggunakan PECS }\end{array}$ \\
\hline 6 & $\begin{array}{l}\text { Postur dan } \\
\text { Motorik Kasar }\end{array}$ & $\begin{array}{l}\text { - Meningkatkan keseimbangan dinamisnya } \\
\text { - Meningkatkan kemampuannya untuk melakukan } \\
\text { tahapan/langkah2 dalam berbagai perpindahan } \\
\text { gerakan } \\
\text { - Meningkatkan kemampuannya untuk } \\
\text { menyeimbangan badan dan melakukan peralihan } \\
\text { kegiatan } \\
\text { - Meningkatkan } \\
\text { posturalnya } \\
\text { - Meningkatkan kekuatan badan untuk perbaikan } \\
\text { motoric halus dan motoric kasar } \\
\text { - Meningkatkan kekuatan bahu } \\
\text { meningkatkan kemampuannya untuk } \\
\text { menyeberangi garis tengah }\end{array}$ \\
\hline
\end{tabular}




\begin{tabular}{|c|c|c|}
\hline & & $\begin{array}{l}\text { - meningkatkan kemampuannya untuk membawa } \\
\text { sikuen saat berkegiatan sambil melakukan } \\
\text { berbagai gerakan }\end{array}$ \\
\hline 7 & Bahasa Ekpresif & $\begin{array}{l}\text { - Meningkatkan kemampuan berkomunikasi } \\
\text { ekspresif melalui kekuatan kata } \\
\text { - Meningkatkan komunikasi ekspresifnya untuk } \\
\text { digunakan di kegiatan terstruktur } \\
\text { - Meningkatkan Bahasa ekspresif untuk } \\
\text { menstrukturkan kalimat tertentu (SPO) } \\
\text { - Memperpanjang kalimat dan memberikan } \\
\text { banyak informasi kepada PK } \\
\text { - Meningkatkan kemampuannya untuk } \\
\text { memberikan informasi } \\
\text { - Meningkatkan kemampuannya } \\
\text { mendiskripsikan Bahasa } \\
\text { Meningkatkan kemampuannya untuk berbahasa } \\
\text { diskriptif }\end{array}$ \\
\hline 8 & Bahasa Reseptif & $\begin{array}{l}\text { - Membangun Kemampuan berbagi perhatian dan } \\
\text { - } \text { Memampuan mendengarkan } \\
\text { - Memahami konsep, memahami letak / preposisi } \\
\text { menggunakan di kalimat/instruksi sederhana } \\
\text { - Memahami konsep, memahami posisi dalam } \\
\text { - } \text { Merintah / instruksi sederhana } \\
\text { - Mengidentifikasi bagian tubuh, bagian objek, } \\
\text { - Memahan bentuk } \\
\text { - Memahamatribut } \\
\text { - Kosong }\end{array}$ \\
\hline 9 & Problem Solving & - Memecahkan masalah \\
\hline 10 & Sensory & $\begin{array}{l}\text { - ikut serta pada kegiatan taktil dengan bermain } \\
\text { plastisin/foam/ cat yang menstimulasi } \\
\text { kemampuannya untuk memfasilitasi berbagai } \\
\text { macam sensasi sentuhan }\end{array}$ \\
\hline 11 & Sosial Skill & $\begin{array}{l}\text { - meningkatkan kemampuannya untuk merespon / } \\
\text { berbagi perhatian } \\
\text { - Membangun Joint Attention } \\
\text { - Mengembangkan kemampuan untuk merespon } \\
\text { Joint Attention }\end{array}$ \\
\hline
\end{tabular}




\begin{tabular}{|c|c|c|}
\hline & & $\begin{array}{l}\text { - Mengembangkan inisiatif untuk melakukan Joint } \\
\text { - } \text { meningkatkan kemampuan untuk trampil dalam } \\
\text { permainan sederhana (sebab akibat ) dan } \\
\text { ketrampilan dalam bergiliran } \\
\text { - meningkatkan kemampuan untuk bermain } \\
\text { sederhana (paralel play) dan mampu bergiliran } \\
\text { - meningkatkan kemampuan untuk berbagi dan } \\
\text { memulai giliran } \\
\text { - meningkatkan kemampuan mengambil giliran } \\
\text { - } \text { Mada permainan kooperatif } \\
\text { - Giliran Di Kegiatan Yang Terstruktur } \\
\text { - Mengembangkan kemampuan dalam menunggu } \\
\text { - meningkatkan kemampuan dalam bermain peran } \\
\text { berinisiatif dan mempertahankan permainan } \\
\text { dengan teman/kelompok } \\
\text { - meningkatkan kemampuan percakapan }\end{array}$ \\
\hline 12 & Bina Diri & $\begin{array}{l}\text { - } \text { Makan } \\
\text { - } \text { Toileting } \\
\text { - } \text { Mempersiapkan Hidangan } \\
\text { - Laundry } \\
\text { - Merapikan Tempat Tidur } \\
\text { - Mengelap } \\
\text { - Menyelesaian Tugas Lain } \\
\text { - Mengenal Uang } \\
\text { - } \text { Kelanja } \\
\text { - Pesenangan } \\
\text { - Mobiliaku Sosial di Tempat Umum } \\
\text { - Keamanan } \\
\text { - Komunikasi } \\
\text { - } \text { Waktu } \\
\text { - } \text { Perlindunganat Diri } \\
\text { - Bekerja/Sekolah }\end{array}$ \\
\hline
\end{tabular}

\section{Melakukan Validasi}

Untuk melihat keefektifan prosedur pengembangan, penelitian ini menggunakan uji validitas baik uji validitas ahli maupun uji public terbatas. Proses validasi ahli adalah menjadi 
bagian vital dalam penelitian pengembangan ini untuk mengetahui ketepatan dan kedalaman hasil pengembangan. Tahap uji ahli melalui evaluasi produk, yaitu meliputi tanggapan ahli isi/konten ke PLB dan Kurikulum, yaitu:

Tabel 3 Tanggapan Ahli dalam Uji Validitas

\begin{tabular}{|c|c|c|c|c|}
\hline Tipe & Nama & Lulusan & $\begin{array}{c}\text { Hasil } \\
\text { Validasi }\end{array}$ & Komentar \\
\hline Isi/Konten & $\begin{array}{l}\text { Dr. Endang } \\
\text { Purbaningrum, } \\
\text { M.Kes }\end{array}$ & $\begin{array}{ll}\text { - } & \text { S3 } \\
\text { Managemen } \\
\text { Pendidikan } \\
\text { - S2 } \\
\text { Pendidikan } \\
\text { Luar Biasa } \\
\text { Dosen PLB } \\
\text { Unesa }\end{array}$ & Layak & $\begin{array}{l}\text { Diharapkan } \\
\text { melengkapi: } \\
\text { - Kata pengantar } \\
\text { - } \quad \text { Daftar table } \\
\text { - Daftar gambar } \\
\text { - Glosarium } \\
\text { - lampiran }\end{array}$ \\
\hline Kurikulum & $\begin{array}{l}\text { Citra } \\
\text { Kholidiya, } \\
\text { M.Pd }\end{array}$ & $\begin{array}{ll}\text { - } & \text { S2 } \\
\text { Kurikulum } \\
\text { dan } \\
\text { Teknologi } \\
\text { Pendidikan } \\
\text { - Dosen } \\
\text { Jurusan KTP } \\
\text { Unesa }\end{array}$ & Layak & $\begin{array}{l}\text { Perlu perbaikan } \\
\text { beberapa indikator }\end{array}$ \\
\hline
\end{tabular}

Selanjutnya, melakukan uji public secara terbatas dengan mengundang para terapis anak berkebutuhan khusus di ULABK Unesa. Hal ini dilakukan untuk mengetahui keefektifan dan kemungkinan penggunaan kurikulum yang telah dikembangkan.

\section{KESIMPULAN}

Berdasarkan hasil analisis dan pengembangan, untuk sementara dapat disimpulkan bahwa: (1) prosedur penelitian pengembangan kurikulum program intervensi anak berkebutuan khusus ini berkerjasama dengan pihak ahli yang representative di bidangnya, khususnya dalam proses validasi nantinya. (2) agar hasil penelitian pengembangan dapat dipertanggungjawabkan secara ilmiah, maka digunakan prosedur ilmiah dalam proses pengembangannya. 


\section{DAFTAR PUSTAKA}

Sudarwan Danim. 2005. Pengantar Studi Penelitian Kebijakan. Jakarta: PT. Bumi Aksara.

Nana Syaodih Sukmadinata 2008. Metode Penelitian Pendidikan, Bandung: PT Remaja Rosdakarya.

LJ. Moloeng. 2009, Metodologi Penelitian Kualitatif, Bandung; PT. Remaja Rosdakarya.

Bristol, M., \& Schopler, E. 1984. A developmental perspective on stress and coping in families of autistic children. In J. Blacher (Ed.), Families of severely handicapped children, New York, NY: Academic Press.

Carpenter, M., \& Tomasello, M. 2000. Joint attention, cultural learning, and language acquisition. In A. Wetherby \& B. Prizant (Eds.), Autism spectrum disorders: A transactional, developmental perspective (pp. 31-54), Baltimore, MD: Brookes.

Carr, E. G., Levin, L., McConnachie, G., Carlson, J., Kemp, D., \& Smith, C. 1994. Communicationbased intervention for problem behavior: A user's guide for producing positive change. Baltimore, MD: Paul Brookes.

Lovaas, O. I. 1981. Teaching developmentally disabled children. The "me” book. Baltimore, MD: University Park Press.

Lucyshyn, J., Dunlap, G., \& Albin, R. 2002. Families and positive behavior support: Addressing problem behavior in family contexts. Baltimore, MD: Paul Brookes.

Lynch, E., \& Hanson, M. (1998). Developing cross-cultural competence: A guide for working with young children and their families (2nd ed.). Baltimore, MD: Paul Brookes Publishing.

Manolson, A. (1992). It takes two to talk. The Hanen Centre Program Manual-Second edition. Toronto: The Hanen Centre.

Maurice, C., Green, G., \& Luce, S. (1996). Behavioral intervention for young children with autism. Austin, TX: Pro-Ed.

McLean, J., \& Snyder-McLean, L. (1978). A transactional approach to early language training. Columbus, $\mathrm{OH}$ : Merrill. 